\title{
Farm animals against open borders: uncovering discrepancies between narratives and evidence regarding actors and motives in the animal trade
}

\author{
Stefan Mann' ${ }^{1}$ (D) Silviu Beciu ${ }^{2,3}$ (iD) Georgiana Armenita Arghiroiu ${ }^{3}$ (i) \\ ${ }^{1}$ Department of Socioeconomics, Agroscope Standort Tanikon 1, 8356, Aadorf, Switzerland. \\ ${ }^{2}$ Bucharest University of Economic Studies, Piaţa Romană, 6, 010374, Bucharest, Romania. E-mail: beciu.silviu@gmail.com. *Corresponding \\ author. \\ ${ }^{3}$ Faculty of Management, Economic Engineering in Agriculture and Rural Development, University of Agronomic Sciences and Veterinary \\ Medicine of Bucharest, Bucharest, Romania. \\ ABSTRACT: The paper examined dominant discourses in the debate about live animal transport and trade before reviewing trade figures \\ from the UN Comtrade database. Between 1998 and 2015, the trade in cattle increased slightly, the trade in pigs increased by $76 \%$, while the \\ trade in poultry increased more than doubled. It is shown that an increased division of work is the driving force behind animal trade and that \\ not even animal advocacy groups are effective in reducing the amount of trade. Largely independent of the ethical framework applied, in an \\ environment that pays increasingly tribute to animal welfare, this is problematic. The paper concluded that animal trade results in externalities \\ that should be internalized by governments. \\ Key words: live animal trade, transport stress, animal welfare.
}

Animais de fazenda contra fronteiras abertas: descobrindo discrepâncias entre narrativas e evidências sobre ponto de vista de diferentes atores

RESUMO: $O$ artigo examina os discursos dominantes no debate sobre o transporte e comércio de animais vivos antes de analisar os dados do comércio da base de dados da ONU Comtrade. Entre 1998 e 2015, o comércio de bovinos aumentou ligeiramente, o comércio de suínos aumentou $76 \%$, enquanto o comércio de aves mais do que duplicou. Demonstra-se que há uma divisão maior do trabalho que é a força motriz por trás do comércio de animais e que nem mesmo os grupos de defesa dos animais são eficazes na redução da quantidade de comércio. Em grande parte, independente do quadro ético aplicado, em um ambiente que qualifica cada vez mais o bem-estar animal, sendo um desenvolvimento problemático. O artigo conclui que o comércio de animais resulta em externalidades que devem ser internalizadas pelos governos.

Palavras-chave: comércio de animais vivos, estresse de transporte, bem-estar animal.

\section{INTRODUCTION}

In spite of the huge body of trade literature, little has been written about the trade of living animals, which can be distinguished from all other forms of trade because it involves living subjects with "the ability to feel pain" (BROOM, 2007). While evidence of the disutility of transporting animals is vast (LAMBOOIJ, 2014; FAZIO et al., 2016; LI et al., 2017), the present paper presupposes that international trade in living animals can serve as a good proxy for disutility generated by transport. This statement can be defended by linking two notions, the first is that the length of transport will be negatively correlated with the animals' utility, an argument that will be expanded upon below. The second is that the number of animals crossing a border and the average transport distance will be positively correlated, which might be difficult to prove but is fair to assume. Based on these assumptions, the paper is concerned with the development and the driving forces of the live animal trade, challenging the dominant narratives about the important motives and actors in an ethically concise and data-driven way.

\section{Methodological approach}

Ethically, the paper aimed to be open to two competing paradigms regarding animal welfare. Conversely, it claims to serve as a starting point for including animals as the subjects in the scientific discourse concerning animal trade, using the trade in farm animals. While the "utility of animals" is typically understood as the utility that animals offer for human purposes (e.g., RUTGERS and HEEGER, 1999; 
WELLS, 2009; BILEWICZ et al., 2011), this paper explored what the inclusion of animals as subjects with their own preferences would mean. However, animal welfare can also be applied in an anthropocentric way. But even if only human's demand for animal welfare matters (and not animal themselves), we claim that our conclusions also apply.

Both approaches are applied for the actual situation and perception of live animal trade. In terms of data, there is two starting points:

The body of available literature on live animal trade had to be analyzed in an integrative and critical way to understand the main ongoing discourses around live animal trade. This includes discourses against animal transports among animal advocacy groups as well as the business-oriented discourse on efficient animal production chains.

Trade data from the United Nation's Comtrade Database (UN Comtrade, 2018) was used to follow trade volumes for the three most important categories of agricultural animals between 1998 and 2015. As the added value of econometric applications appeared small, a descriptive analysis of volumes and values over time was carried out.

\section{Discourses on the animal trade}

In many cases, discourses can be divided into scientific and social discourses (e.g., BUSCH, 2016). The case of the animal trade is no exception to that rule.

On the scientific side, researchers working on the international animal trade are usually others than the ones that work on animal transport issues. Indeed, the few publications that explicitly focus on international animal transportation (i.e., the animal trade) often center on the epidemiological aspects of animal trade in terms of disease spreading (MARANO et al., 2007; PFEFFER and DOBLER, 2010; RANTUREAU et al., 2011). The literature concerning animal transport in general is richer. Authors often feature scientific indicators of the stress that animals face while being transported (GRANDIN, 1997; PALME et al., 2000; KNOWLES and WARRIS, 2007; SCHWARTZKOPF-GENSWEIN et al., 2012), sometimes with a focus on the deteriorating quality of the meat (YOUNG and GREGORY, 2001; HONKAVAARA et al., 2003; FERGUSON and WARNER, 2008) or animal health (TODD et al., 2000). In other cases, methods of reducing stress levels during transportation (SCHAEFER et al., 1997 ) or the hygienic impacts of animal transports are explored (BACH et al., 2004).

The social discourse concerning animal trade knows governmental and non-governmental actors. Among the first, the European Food Safety Authority (EFSA, 2011) is a good example for repeated public attempts to define both minimum requirements and best practice for animal transports. Aside from very few voices of farmers critically commenting on the additional trade restrictions placed on the animal trade (LEHNERT, 2014) or recording trade flows (ANONYMOUS, 2016), the non-governmental side is dominated by animal advocacy groups. Few groups are specialized in the issue of animal transport and/or the animal trade:

The Dutch advocacy organization "Eyes on Animals" focuses on the transport of animals. If legal restrictions are breached, the group forwards this information to public control organizations and publishes it on their website. The group also offers education and advice to highway patrols and other relevant control organizations.

The German "Animals' Angels" have a very similar profile; although, they strongly emphasize assistance during transportation, providing, for example, water to animals waiting at a border.

Other advocacy organizations have much broader profile; although, they also include the issue of animal transport in their profile:

The NGO "World Animal Protection" is arguably the most global advocacy group that is active against animal transport, also supporting the elaboration of scientific evidence of stressful effects of animal transports (APPLEBY, 2008).

The British "Born Free Foundation" mainly works against the use of animals in zoos and circuses, but some national subsidiaries, such as the US branch, also actively campaign against the international transport of animals (ANONYMOUS, 2009).

Germany's largest animal advocacy group, the "Deutscher Tierschutzbund", has collected signatures calling German government to institute a ban against animal transport outside the European Union (EU), arguing that strict rules governing animal transportation cannot be enforced outside the EU.

There also exists a small body of literature reflecting on advocacy organizations works. Some researchers focus on a comprehensive description of such organizations' activities, focusing either on past (FERGUSON, 1998; PHELPS, 2007) or present (KEMMERER, 2012). Others focus on women dominance (GAARDER, 2011) or the children potential (PATTNAIK, 2004) within advocacy organizations. DALZIELL and WADIWELL (2016) are among the few scholars to report a positive case of advocacy, which they label "one of the most successful animal advocacy campaigns in recent 
Australian history." This judgement is largely confirmed by VILLANUEVA (2018). In this case, following media reports about the undue treatment of animals in Indonesia and subsequent campaigns, the Australian government stopped live animal exports to Indonesia for several months.

One recurring theme in the literature concerning the animal trade is religion. GRANDIN (2008), for example, considers the fact that "many customers want raw meat", a secular description for Halal slaughtering and processing, is the primary reason for trading live animals rather than meat. It is not only popularly known that potential conflicts exist between traditional Jewish and Muslim practices and animal welfare, it is also discussed broadly among scientists from different disciplines (GRANDIN and REGENSTEIN, 1994; JUDD, 2003; LEVER and MIELE, 2012). Examples from animal advocates also often use examples like bovine transports from Brazil to the Middle East (AUFHAUSER, 2008), referring only indirectly to religious motives.

Taken together, the situation based on the literature alone appears to be in reasonable balance: While cruelties still occur, both NGO's and governmental bodies appear to steer the situation into the right direction, without having farmers complaining too loudly. Particularly religion seems to be a serious motive that still necessitates the transports of live animals, but animals' interests are well represented by advocacy organizations.

\section{Evidence concerning the live animal trade}

Figure 1 is based on Comtrade data as described in Section 2. It compares the dynamics of the trade in cattle, pigs, and poultry between 1998 and 2015 by displaying the quantities and deflated values. Around 2 million tons of cattle and pigs are traded between countries, while in poultry, the amount is approaching 1.5 million tons. However, while these figures are similar, the dynamics behind them are not. Bovine trade remained largely constant over the study period, with the quantities expanding by only $5.6 \%$, while the quantities of global exports of pigs increased by $76 \%$. Moreover, the trade in living poultry more than doubled within the study period.

The blue line, which indicates value, shows that animal prices soared during the first decade of the study period, before decreasing again from around 2013. The average prices, during the period shown, have followed an inverse U-shape.

It should be recognized that the three categories included in figure 1 depicted more than $90 \%$ of the total farm animal trade. Sheep and goats together are constantly traded in quantities of around 500,000 tons, while the trade in horses, donkeys, and mules decreased between 1998 and 2015 from 180,000 tons to 100,000 tons.

Figures 2 and 3 provide greater geographical detail, indicating all trade flows of pigs above 20,000 tons. This amount would equal 250,000 hogs ready for abattoir, although, it is likely that more animals are actually involved, since many countries, such as Denmark and Canada, are known for exporting large quantities of piglets (HALEY, 2005; ANONYMOUS, 2016).

Figure 2 indicates the three major trading blocs for pigs. In North America, pigs were traded southwards, while a few East Asian countries transport them, including a supply of Chinese pigs into Hong Kong. Most trade flows, however, occurred in the newly liberalized EU market. Again, mostly in a southern direction.

In 2015, as figure 3 indicates, two of the three trading blocs changed shape to a very mild extent. China, now the world's largest pork producer, still supplies pigs to Hong Kong, while

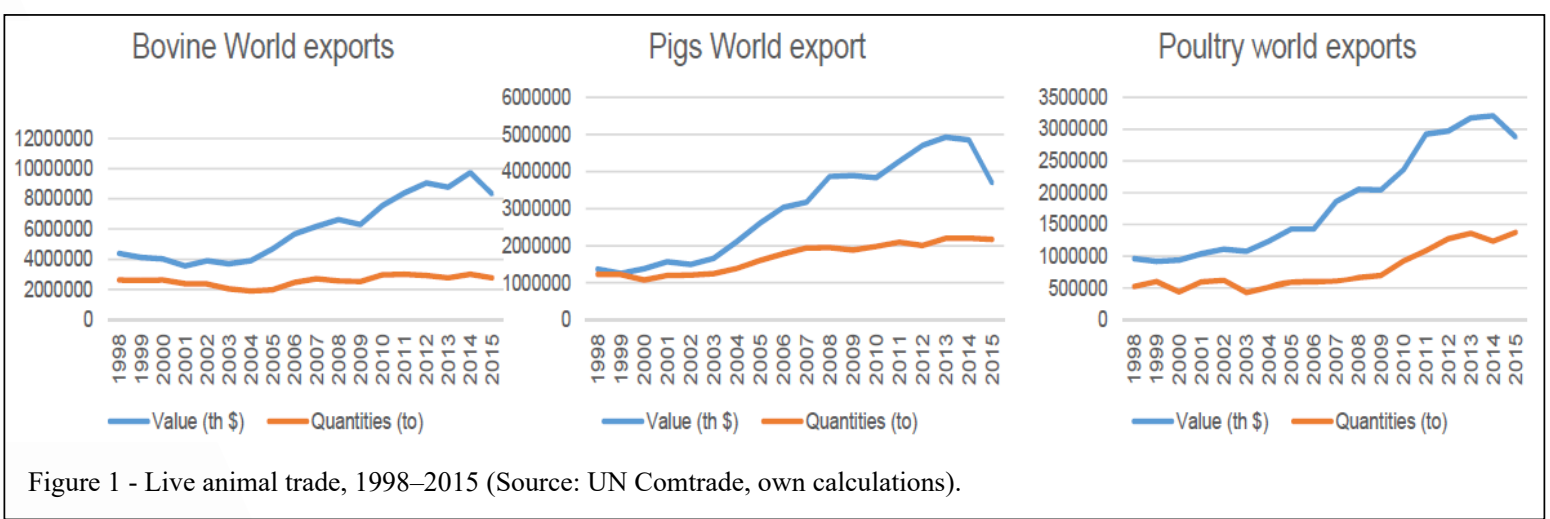

Ciência Rural, v.49, n.3, 2019. 


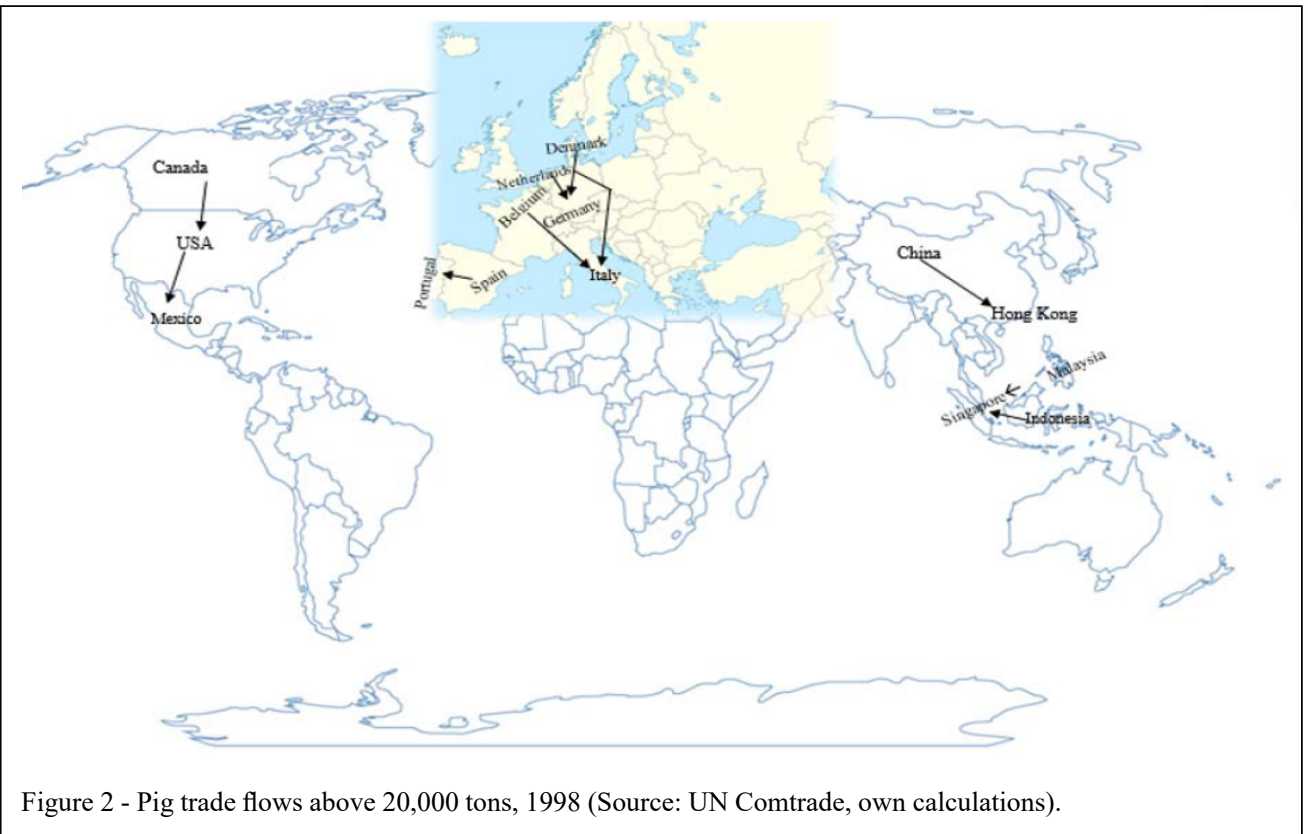

North American feeder pigs are still transported southwards. In Europe, however, the trade apparently intensified considerably. Southbound transportation routes have been extended to the newly admitted EU member states, including Poland, Slovakia, and
Hungary. In addition, northbound routes have been added, for example, from France to Belgium and from Belgium to the Netherlands. Moreover, Austria has started to import pigs from Germany. A lot of dynamics have been added, and the EU's share of the

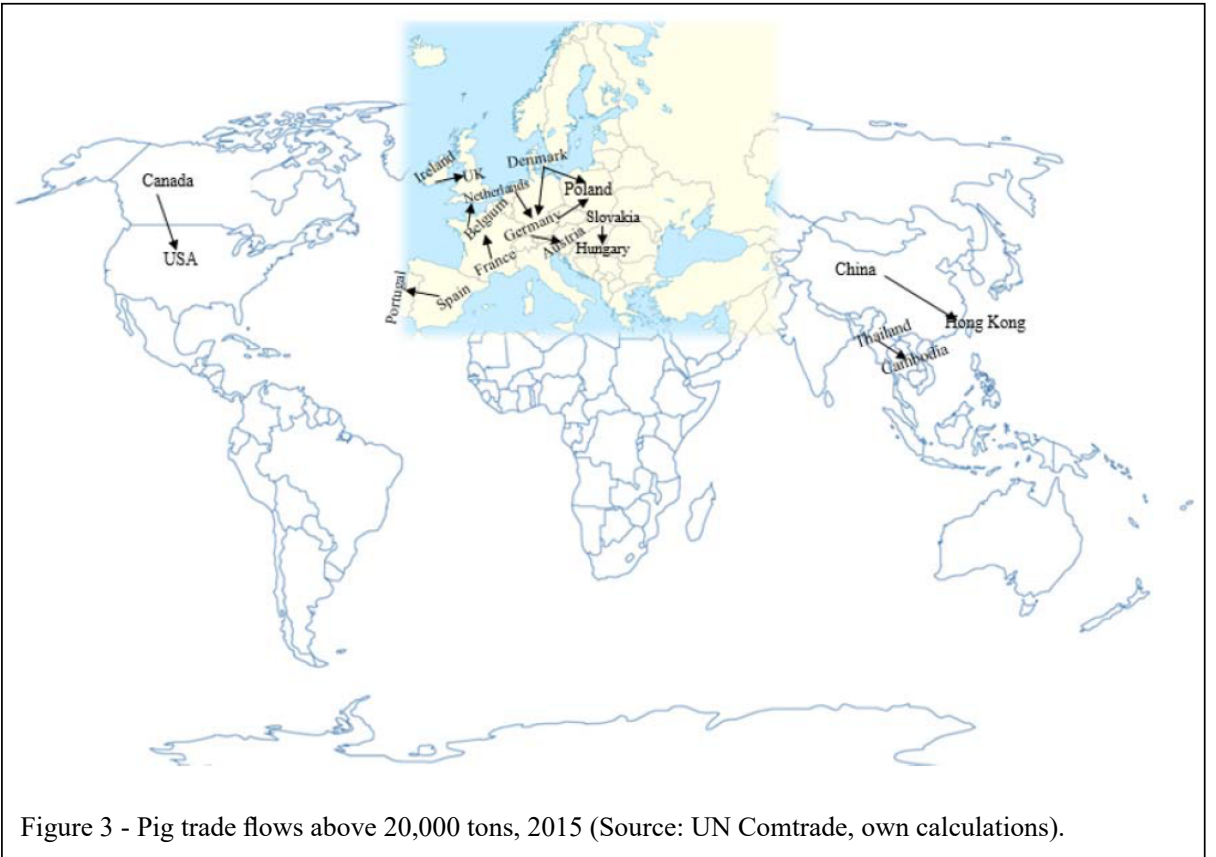

Ciência Rural, v.49, n.3, 2019. 
total world exports of pigs increased from $47 \%$ in 1998 to $73 \%$ in 2015 .

The expansion of the trade in pigs from Canada to the United States, while not visible from the figures, motivated HALEY (2005) to explain the dynamic development, citing trade figures of 921,000 hogs in 1994 and 8 million in 2004. She showed a decrease in breeding herds in the USA and a simultaneous increase in Canada. She further relied on the higher breeding efficiency of Canadian hog producers (a difference of $29 \%$ ) to conclude that "pork production in North America is arguably an application of the theory of comparative advantage. Canada mainly specializes in the stage of pork production where it is most efficient-feeder pig production-and the United States tends to specialize in finishing hogsparticularly in the Corn Belt States, where costs of corn and soybean meal are minimized-and in processing finished hogs in large-scale processing facilities that can minimize costs. Consumers in North America and Asia reap the benefits of lowcost, high-quality pork products."

Tables 1 and 2 depicted the ten largest trade flows for the - less dynamic - market for cattle and the - more dynamic - market for poultry, respectively. Regarding cattle, the two most important streams of animals have slowed down. Following the North American Free Trade Agreement (NAFTA), the duty-free Canadian export of cattle to the United States was close to its peak in 1998 (GUINN and SKAGGS, 2005). Since then, however, other nations have emerged as growing cattle exporters, most notably Australia, with an export market share of $14 \%$ in 2015 , which apparently sent its cattle on even longer journeys, including to recipients such as Vietnam, but also Brazil.

Although, the poultry trade is expanding more quickly than any other branch of the animal trade, there is hardly any public information available about motives behind trade. It therefore, remains highly uncertain to which share chicks are dispatched and to what extent fattened chickens are sent to foreign abattoirs. It is clear, however, that the Netherlands has been among the most active actors in this realm, and that country has hence increased its share. Imports from Germany now constitute more than a third of the worldwide trade, although, there are also exports in the opposite direction and a smaller exchange with Belgium.

Similar to the situation for pigs, the new trade flows seen in the table are partly due to a new opening of borders. Most particularly, this applies to exports from Romania to Hungary and from Poland to Germany, which opened their borders due to EU enlargement.

\section{Comparing narratives to evidence}

The discourses cited in Section 2 do not usually refer to worldwide trade figures concerning live farm animals, which, to the best of our knowledge, have never been evaluated before in a systematic manner. It is therefore, unsurprising that the figures, in some respects at least, offer a contradictory perspective to the main lines of debate. This concerns to the main drivers of the trade and the role of animal advocacy, two aspects that deserve greater reflection.

\section{It's capitalism, not religion}

The demand for halal and kosher meat is not the major reason for transporting farm animals

Table 1 - The main trade flows of cattle (Source: UN Comtrade, own calculations).

\begin{tabular}{|c|c|c|c|c|c|}
\hline Exporting country & Importing country & Quantities (to) & Exporting country & Importing country & Quantities (to) \\
\hline Canada & USA & 765429 & Canada & USA & 411887 \\
\hline France & Italy & 328051 & France & Italy & 281983 \\
\hline Mexico & USA & 142703 & Mexico & USA & 254901 \\
\hline USA & Mexico & 93852 & Australia & Indonesia & 195418 \\
\hline Germany & Netherlands & 81794 & Australia & Vietnam & 117234 \\
\hline Australia & Philippines & 74296 & Brazil & Venezuela & 58736 \\
\hline France & Spain & 71702 & Ethiopia & Somalia & 53530 \\
\hline Australia & Libya & 51653 & France & Spain & 41392 \\
\hline Columbia & Venezuela & 48723 & Uruguay & Turkey & 36680 \\
\hline Australia & Egypt & 48333 & Burkina Faso & Benin & 36000 \\
\hline
\end{tabular}

Ciência Rural, v.49, n.3, 2019. 
Table 2 - The main trade flows of poultry (Source: UN Comtrade, own calculations).

\begin{tabular}{|c|c|c|c|c|c|}
\hline Exporting country & Importing country & Quantities (to) & Exporting country & Importing country & Quantities (to) \\
\hline Germany & Netherlands & 94735 & Germany & Netherlands & 508644 \\
\hline Malaysia & Singapore & 65492 & Malaysia & Singapore & 108886 \\
\hline China & Hong Kong & 46812 & Netherlands & Belgium & 84204 \\
\hline Netherlands & Belgium & 29875 & France & Belgium & 67445 \\
\hline USA & Canada & 25733 & Belgium & Netherlands & 53054 \\
\hline France & Belgium & 18334 & Netherlands & Germany & 33235 \\
\hline USA & $\begin{array}{l}\text { Netherlands } \\
\text { Antilles }\end{array}$ & 18000 & Romania & Hungary & 30467 \\
\hline Belgium & Netherlands & 11981 & Slovakia & Poland & 27594 \\
\hline Netherlands & Germany & 10944 & Denmark & Germany & 21474 \\
\hline France & Netherlands & 4831 & Netherlands & Poland & 19809 \\
\hline
\end{tabular}

across borders. Indeed, only very few of the trade flows described in the previous section can potentially be attributed to Muslim or Jewish traditions.

Of the 30 most important trade flows in 2015 (i.e., the top ten for pigs, cattle, and poultry), some 19 are situated within the EU, while zero exist between an EU country and a country outside the EU. Together with the duty-free NAFTA trade in North America, this fact indicates that open borders are - by far - the most important driver of the animal trade. While animal advocates point out cattle transports from Brazil to the Middle East (see Section 3), Brazilian cattle transports to Venezuela have become much more important.

It appears that certain costs can be saved, due to different comparative advantages, if animals are bred in Country A, fattened in Country B, and then slaughtered in Country C. As these savings are not huge, even moderate tariffs seem to prevent, or at least strongly reduce, trade.

From a utilitarian perspective, the situation would be rather more defendable if religion did play a more important role. In such cases, the disutility of animals being transported over long distances might be compensated by the additional utility obtained by faithful, who can produce their meat in the manner they prefer. Instead, the only potential utility to weigh against the animals' disutility is the very slightly lower cost of a steak, an egg, or a bottle of milk.

\section{Animal advocacy has not been successful}

A particularly illustrative case has been reported from Down Under. Readers may recall that the case against animal exports from Australia to Indonesia was labelled as one of the most successful animal advocacy campaigns in recent Australian history, since the Australian government banned such exports for several months in 2007. Yet, attentive readers may already have observed from Table 1 that cattle exports from Australia to Indonesia was the top 5 in 2015, whereas they were not even among the top 10 in 1998. This appears to be symptomatic: even the most successful campaigns make only a faint dent in the booming worldwide market for live animals.

The focus of some advocacy groups may additionally hamper their effectiveness. It has previously been mentioned that the Deutscher Tierschutzbund focuses on lobbying against animal exports outside the EU. It argued that such transportation often fails to comply with legal guidelines after leaving the EU. However, this argument is weak, since there is ample evidence concerning non-compliance within the EU itself (e.g., EYES ON ANIMALS, 2015). Additionally, it takes attention away from the vast majority of animal transports, which take place within the EU.

Nevertheless, it is not difficult to explain the perception of advocacy campaigns as successes. Based on the rationale of public choice theory (BUCHANAN and TOLLISON, 1984), one can assume that advocacy organizations strongly rely on success stories in order to convince donors that their money is being well spent. NGO's have an incentive to overemphasize the benefit of the smallest step forward, not to point to the apparently unstoppable growth of the animal trade. Further, no other actors have any incentive to question such success stories. 
Farm animals against open borders: uncovering discrepancies between narratives and evidence regarding actors and motives in the animal...

The industry wants to draw attention away from the unpopular transportation of animals, instead focusing on selling their final products. Meanwhile, the agenda of the state is concerned with keeping the discussion under control, something that is easier to achieve if success in terms of animal friendliness is reported.

One could go so far as to claim that advocacy groups focus more strongly on selling a warm glow than on helping animals. This might be a necessary strategy for economic survival, but it highlighted the lack of societal forces that can effectively limit the transport of animals.

\section{DISCUSSION AND CONCLUSION}

One of the main narratives among economists is the notion that trade generates additional utility as countries can focus on their strengths. From an anthropocentric viewpoint, the figures regarding the farm animal trade confirm this notion. As soon as trade barriers are removed, countries are able to fully play to their strengths in terms of breeding animals, fattening them, or slaughtering them. The opening of borders, be it in North America or Europe, is likely to reduce the production costs of a kilogram of meat and a liter of milk through facilitating the establishment of efficient supply chains.

There is, however, a societal demand for animal welfare. The growing number of vegetarians and even vegans, as well as the increasing use of animal welfare labels and the growing number of animal advocacy NGOs, make it clear that a significant share of the population cares about animals wellbeing. It continues to be controversial debate concerning the question of whether or not animals have rights. Even if they do not, however, a truly utilitarian perspective should take animal preferences into account. Moreover, even if this would prove to be an unrealistic agenda with the adoption of the anthropocentric perspective that only the well-being of humans matters, the welfare of animals affects the welfare of humans.

Through the work of animal advocacy organizations, a political equilibrium exists that accounts for this component. Yet, utilitarians always emphasize the fact that decisions should be based on informed preferences (HARSANYI, 1995; RABINOWICZ and ÖSTERBERG, 1996; NG, 1999). This is not currently the case. Animal advocacy organizations have an incentive to claim that their work is effectively curbing the transport of animals, preventing the worst scenario, while the average farm animal is transported over ever-increasing distances.

\section{ACKNOWLEDGEMENTS}

No financial support or felloships or schoarships have been provided for this paper.

\section{DECLARATION OF CONFLICT OF INTERESTS}

The authors declare no conflict of interest. The founding sponsors had no role in the design of the study; in the collection, analyses, or interpretation of data; in the writing of the manuscript, and in the decision to publish the results.

\section{AUTHORS' CONTRIBUTIONS}

All authors contributed equally for the conception and writing of the manuscript. All authors critically revised the manuscript and approved of the final version.

\section{REFERENCES}

ANONYMOUS Born Free USA Primate Sanctuary Director. In Wildlife Disease Association: Newsletter, April 2009, p.28

ANONYMOUS Mehr lebende Tiere eingeführt. 2016, Available from: <https://www.bwagrar.de/Tierhaltung/Schwein/Mehr-lebendeTiere-eingefuehrt,QUIEPTUxOTczMDQmTUIEPTUyOTI0.html>. Accessed: Jan. 17, 2018

APPLEBY, M. V. et al. Long Distance Transport and Welfare of Farm Animals. 2008, Wallingford: CAB International.

AUFHAUSER, M. Paradise for Rescued Animals. Kempen: teNeues. 2008.

BACH, S. J. et al. Long-Haul Transport and Lack of Preconditioning Increases Fecal Shedding of Escherichia coli and Escherichia coli O157:H7 by Calves. Journal of Food Protection: April 2004, Vol.67, No.4, pp.672-678. Available from: $<$ https://jfoodprotection. org/doi/abs/10.4315/0362-028X-67.4.672>. Accessed: Feb. 20, 2018 doi: $10.4315 / 0362-028 X-67.4 .672$.

BILEWICZ, M. et al. The humanity of what we eat: Conceptions of human uniqueness among veterinarians and omnivores. European Journal of Social Psychology, 41 (2) 201-209, 2011. Available from: <https://onlinelibrary.wiley.com/doi/full/10.1002/ejsp.766>. Accessed: Mar. 17, 2018. doi: 10.1002/ejsp.766.

BROOM, D.M. Cognitive ability and sentience: Which aquatic animals should be protected? Diseases of aquatic organisms, 75 (2) 99-108, 2007. Available from: <https://www.int-res.com/ abstracts/dao/v75/n2/p99-108/>. Accessed: Jan. 20, 2018. doi: 10.3354/dao075099.

BUChanan, J.M., TOLliSON, R.D. The Theory of Public Choice. Ann Arbor: University of Michigan Press, 1984.

BUSCH, K.C. Polar Bears or People? Exploring Ways in Which Teachers Frame Climate Change in the Classroom. International Journal of Science Education, 6 (2) 137-165, 2016. Available from: <https://www.tandfonline.com/doi/full/10 $.1080 / 21548455.2015 .1027320>$. Accessed: Jan. 21, 2018. doi: 10.1080/21548455.2015.1027320.

Ciência Rural, v.49, n.3, 2019. 
DALZIELL, J., WADIWEL, D.J. Live Exports. Animal Advocacy, Race and 'Animal nationalism'. In A. Potts: Meat Culture. Leiden: Brill Academic Pub., 2016.

EFSA Scientific Opinion Concerning the Welfare of Animals during Transport. EFSA Journal, 9 (1): 1966, 2011, Available from: $<$ https:// efsa.onlinelibrary.wiley.com/doi/epdf/10.2903/j.efsa.2011.1966>. Accessed: Feb. 20, 2018.

EYES ON ANIMALS, Shame on Dutch transport company IntoEurope BV (aka Diepeveen), 2015. Available from: $<$ https:// www.eyesonanimals.com/shame-on-dutch-transport-companydiepeveen/>. Accessed: Jan. 25, 2018.

FAZIO, F. et al. Erythrocyte osmotic fragility in response to a short road transport in cattle, horses, and goats. Journal of Veterinary Behaviour, 12 (1) 82-84, 2016. Available from: <https://www. sciencedirect.com/science/article/pii/S1558787815001938>. Accessed: Feb. 3, 2018. doi: 10.1016/j.jveb.2015.11.003.

FERGUSON, D.M., WARNER, R.D. Have we underestimated the impact of pre-slaughter stress on meat quality in ruminants?, Meat Science, 80 (1), 12-19, 2008. Available from: <https://www.ncbi. nlm.nih.gov/pubmed/22063165>. Accessed: Feb. 5, 2018. doi: 10.1016/j.meatsci.2008.05.004

FERGUSON, M. Animal advocacy and Englishwomen. Ann Arbor: University of Michigan Press, 1998.

GAARDER, E. Where the Boys Aren't: The Predominance of Women in Animal Rights Activism. Feminist Formations, 23 (2), 54-76, 2011. Available from: <https://fewd.univie.ac.at/fileadmin/ user_upload/inst_ethik_wiss_dialog/Gaarder_Emily_2011. Where the_Boys_Arent.pdf $>$. Accessed: Feb. 3, 2018.

GRANDIN, T. Assessment of stress during handling and transport Journal of Animal Science, 75 (1), 249-257, 1997. Available from: $<$ https://www.grandin.com/references/handle.stress.html $>$. Accessed: Jan. 16, 2018 .

GRANDIN, T. Foreword: Strategies to Improve Farm Animal Welfare and Reduce Long Distance Transport of Livestock Going to Slaughter. In V. Cussen, L. Garces: Long Distance Transport and Welfare of Farm Animals. Wallingford: CAB International, 2008.

GRANDIN, T., REGENSTEIN, J.M. Religious slaughter and animal welfare: a discussion for meat scientists. Meat slaughter International, 3/1994, 115-123, 1994. Available from: <https:// mountainscholar.org/bitstream/handle/10217/4444/HS115. pdf? sequence $=1$ \&isAllowed $=\mathrm{y}>$. Accessed: Jan. 17, 2018.

GUINN, C. SKAGGS, R. North American Beef and Cattle Trade: A Current Perspective. Technical Report 40. Les Cruces: New Mexico State University, 2005.

HALEY, M. U.S.-Canadian Hog Trade: Market Integration at Work. Amber Waves, 1.2.2005. Available from: < https://www. ers.usda.gov/amber-waves/2005/february/us-canadian-hog-trademarket-integration-at-work/>. Accessed: Feb. 7, 2018.

HARSANYI, J.C. A theory of prudential values and a rule utilitarian theory of morality. Social Choice and Welfare, 12 (4) 319-333, 1995. Available from: <https://www.jstor.org/stable/41106139>. Accessed: Feb. 17, 2018.

HONKAVAARA, M. et al. Meat quality and transport stress of cattle. Deutsche Tierärztliche Wochenschrift, 110 (3), 125-
128, 2003. Available from: <https://www.ncbi.nlm.nih.gov/ pubmed/12731114>. Accessed: Feb. 17, 2018.

JUDD, R. The Politics of Beed: Animal Advocacy and the Kosher Butchering Debates in Germany. Jewish Social Studies, 10 (1) 117-150, 2003. Available from: $<$ https://muse.jhu.edu/issue/6169>. Accessed: Feb. 17, 2018. doi: 10.1353/jss.2003.0031.

KEMMERER, L. Animals and World Religions. Oxford: Oxford University Press, 2012.

KNOWLES, T., WARRISS, P. Stress Physiology of Animals during transport. In T. Grandin: Livestock Handling and Transport. Wallingford: CAB International, 2007.

LAMBOOIJ, E. Transport of pigs. In T. Grandin: Livestock Handling and Transport. Wallingford: CAB International, 2017 LEHNERT, H. Schweineexport wird teurer. Top agrar, 16.5.14, p. 35, 2014 Available from: <https:/www.topagrar.com/schwein/ news/holland-schweineexport-wird-teurer-9564893.html>. Accessed: Feb. 7, 2018.

LEVER, J., MIELE, M. The growth of halal meat markets in Europe: An exploration of the supply side theory of religion. Journal of Rural Studies, 28 (4), 528-537, 2012. Available from: <http://orca.cf.ac.uk/29552/>. Accessed: Jan. 17, 2018. doi: 10.1016/j.jrurstud.2012.06.004.

LI, Z. et al. Transport stress induces weight loss and heart injury in chicks: disruption of ionic homeostasis via modulating ion transporting ATPases. Oncotarget, 8, (15) 24142-24153, 2017. Available from: <http://www.oncotarget.com/index.ph p journal $=$ oncotarget $\&$ page $=\operatorname{article} \&$ op $=$ view $\&$ path []$=159$ 03\&path []$=50846>$. Accessed: Jan. 27, 2018. doi: 10.18632/ oncotarget. 15903 .

MARANO, N. et al. Impact of Globalization and Animal Trade on Infectious disease ecology. Emergence of Infectious Diseases, 13 (12) 1807-1809, 2007. Available from: <https://wwwnc.cdc. gov/eid/article/13/12/07-1276_article>. Accessed: Jan. 27, 2018. doi: 10.3201/eid1312.071276.

NG, Y. K Utility, informed preference, or happiness: Following Harsanyi's argument to its logical conclusion. Social Choice of Welfare, 16 (2) 197-216, 1999. Available from: <https://www. ncbi.nlm.nih.gov/pubmed/30008062>. Accessed: Jan. 27, 2018. doi: $10.1007 / \mathrm{s} 003550050$

PALME, R. et al. Transport stress in cattle as reflected by an increase in faecal cortisol metabolite concentrations. Veterinary Record, 146 (4) 108-109, 2000. Available from: <https:// veterinaryrecord.bmj.com/content/146/4/108>. Accessed: Jan. 26, 2018. doi: 10.1136/vr.146.4.108

PATTNAIK, J. On Behalf of their animal friends: involving children in animal advocacy. Childhood Education, 81 (2) 95-100, 2004. Available from: <https://www.researchgate.net/ publication/254295630_On_Behalf_of_Their_Animal_Friends Involving_Children_in_Animal_Advocacy>. Accessed: Jan. 18, 2018. doi: 10.1080/00094056.2005.10522248.

PFEFFER, M., DOBLER, G. Emergence of zoonotic arboviruses by animal trade and migration. Parasites \& Vectors, 2010, 3-35, 2010. Available from: $<$ https://parasitesandvectors.biomedcentral. com/articles/10.1186/1756-3305-3-35>. Accessed: Jan. 18, 2018. doi: 10.1186/1756-3305-3-35

Ciência Rural, v.49, n.3, 2019. 
Farm animals against open borders: uncovering discrepancies between narratives and evidence regarding actors and motives in the animal...

PHELPS, N. The Longest Struggle: Animal Advocacy from Pythagoras to PETA. Herndon: Lantern Books, 2007.

RABINOWICZ,W.,ÖSTERBERG,J.ValueBasedonPreferences:OnTwo Interpretations of Preference Utilitarianism. Economics \& Philosophy, 12 (1) 1-27, 1996. Available from: <https://www.cambridge.org/core/ journals/economics-and-philosophy/article/eap-volume-12-issue-1cover-and-back-matter/F914E0D98944D8997E6990367F76B9A8>. Accessed: Jan. 18, 2018. doi: 10.1017/S0266267100003680.

RANTUREAU, S. et al. Vulnerability of Animal Trade Networks to the spread of infectious diseases. Transboundary and emerging diseases, 58 (2) 110-120, 2011. Available from: $<$ https://onlinelibrary. wiley.com/doi/full/10.1111/j.1865-1682.2010.01187.x>. Accessed: Jan. 28, 2018. doi: 10.1111/j.1865-1682.2010.01187.x.

RUTGERS, B., HEEGER, R. Inherent worth and respect for animal integrity. In M. Dol: Recognizing the Intrinsic Value of Animals: Beyond Animal Welfare. Amsterdam: Gorcum, 1999.

SCHAEFER, A.L. et al. The use of electrolyte solutions for reducing transport stress. Journal of Animal Science, 75 (1) 258-265, 1997. Available from: <https:/www.ncbi.nlm.nih.gov/ pubmed/9027574>. Accessed: Feb. 10, 2018.

SCHWARTZKOPF-GENSWEIN, K.S. et al. Road transport of cattle, swine and poultry in North America and its impact on animal welfare, carcass and meat quality: A review. Meat Science, 92 (3) 227-243, 2012. Available from: <https://www.ncbi.nlm.nih. gov/pubmed/22608833>. Accessed: Feb. 12, 2018. doi: 10.1016/j. meatsci.2012.04.010.

TODD, S.E. et al. Effects of food withdrawal and transport on 5- to 10-day-old calves. Research in Veterinary Science, 68 (2) 125-134, 2000. Available from: <https://europepmc.org/ abstract/med/10756129>. Accessed: Feb. 10, 2018. doi: 10.1053/ rvsc. 1999.0345 .

\section{UN Comtrade, 2018. UN Comtrade Database.}

VILLANUEVA, G. Animal Rights Without Borders: Lyn White and Transnational Investigative Campaigning. In $\mathrm{S}$. Berger, S. Scalmer: The Transnational Activist. Heidelberg: Springer, 2018.

WELLS, D.L. The effects of animals on human health and well-being. Journal of Social Issues, 65 (3) 523-543, 2009. Available from: < https://spssi.onlinelibrary.wiley.com/doi/full/10 $.1111 /$ j.1540-4560.2009.01612.x>. Accessed: Feb. 17, 2018. doi: 10.1111/j.1540-4560.2009.01612.x.

YOUNG, O.A., GREGORY, N.G. Carcass Processing: Factors Affecting Quality. In Y.H. Hui, W.-K. Nip, R. Rogers: Meat Science and Applications. Boca Raton: CRC Press, 2001. 